\title{
Survey of Ornamental Nurseries in Florida Participating in the U.S.-Canadian Greenhouse Certification Program
}

\author{
Joyce L. Merritt ${ }^{1,8}$, Ellen Dickstein ${ }^{1}$, Robert S. Johnson ${ }^{2}$, \\ Michael Ward ${ }^{2}$, Robert J. Balaam ${ }^{3}$, Carrie L. Harmon ${ }^{1}$, \\ Philip F. Harmon ${ }^{1}$, G. Shad Ali ${ }^{4}$, Aaron J. Palmateer ${ }^{5}$, \\ Timothy Schubert ${ }^{6}$, and Ariena H.C. van Bruggen ${ }^{1,7}$
}

AdDitional InDEx words. Canada, emerging pests and diseases, exports, floriculture, imports, ornamental plants

SumMARY. The purpose of this study was to evaluate the U.S.-Canadian Greenhouse Certification Program (USGCP) that was initiated in 1998. A survey consisting of 34 questions was designed and $\mathbf{4 3}$ out of $\approx \mathbf{4 8}$ nurseries in Florida participating in the USGCP were visited. Based on the answers to the questionnaire, most of the nurseries were in compliance with the majority of USGCP requirements, growers were satisfied with the program, and there was an economic benefit to participating in the program. The main problems identified were the ambiguous wording of some of the requirements and the impracticality of keeping imported and domestic plants completely segregated. Moreover, many of the respondents did not have a written description of a pest management plan. Chi square statistical analysis showed that there was almost no difference between nursery groups in their responses to the majority of the survey questions, indicating that the USGCP is a successful program for both large and small nurseries. This quantitative assessment of the USGCP is the first assessment conducted for this program and discussed in a peer-reviewed publication.

$\mathrm{T}$ The international trade in ornamental plants has increased worldwide in the last several years, with a considerable economic value to exporting countries (Lopian, 1994). According to the U.S. Department of Agriculture (USDA), National

\footnotetext{
This project was funded through the Farm Bill 2008 Section 10201(d) Cooperative Agreement Program from the U.S. Department of Agriculture, Animal and Plant Health Inspection Service.

We thank Dr. Matthew Smith and Dr. Ganyu Gu for their critical review of this manuscript.

${ }^{1}$ University of Florida, IFAS, Department of Plant Pathology, 1453 Fifield Hall, Gainesville, FL 32611

${ }^{2}$ U.S. Department of Agriculture, Animal and Plant Health Inspection Service, Plant Protection and Quarantine, 4700 River Road, Riverdale, MD 20737

${ }^{3}$ U.S. Department of Agriculture, Animal and Plant Health Inspection Service, Plant Protection and Quarantine, 13601 Old Cutler Road, Miami, FL 33158

${ }^{4}$ University of Florida, IFAS, Department of Plant Pathology, Mid-Florida Research and Education Center, 2725 Binion Road, Apopka, FL 32703

${ }^{5}$ University of Florida, IFAS, Department of Plant Pathology, Tropical Research and Education Center, University of Florida, 18905 S.W. 280 Street, Homestead, FL 33031

${ }^{6}$ Florida Department of Agriculture and Consumer Services, Division of Plant Industry, 1911 SW 34th Street, Gainesville, FL 32608

${ }^{7}$ University of Florida, Emerging Pathogens Institute, Gainesville, FL 32611

${ }^{8}$ Corresponding author. E-mail: joycem@ufl.edu.
}

Agriculture Statistics Service (NASS), in 2007 , there were $\approx 18,670$ greenhouse operations with floriculture crops in the United States with 820 million square feet in production. The total sale value of floricultural crops was $\$ 6.5$ billion in 2007 (USDA-NASS, 2007a). In addition to the domestic production, the USDA-Agricultural Quarantine Activity System (AQAS) reports that $\approx 1.2$ billion ornamental plants were imported into the United States in 2010 (calculated from the USDA-AQAS internal database in 2011). The value of these imported ornamental plants was $\approx \$ 1.5$ billion [USDA, Foreign Agricultural Service (FAS), 2011].

In Florida, there were 1598 floriculture operations with 256 million square feet under glass and a total floriculture sale value of $\$ 909$ million in 2007 (USDA-NASS, 2007b). In 2010 , Florida produced $72 \%$ of all the finished ornamental foliage plants grown in the United States with a total wholesale value of $\$ 412$ million (USDA-NASS, 2011). The low number of floriculture operations reported for Florida as compared with the United States (1598 for Florida vs. 18,670 for the United States) is likely due to differences in what types of nurseries are included in these statistics. About 874 million ornamental plants were imported into Florida in 2010 (calculated from the USDA-AQAS internal database in 2011), amounting to $\approx \$ 800$ million (USDA-FAS, 2011 ). About $71 \%$ of all live ornamental plants that entered the United States in 2010 came in through Florida (calculated from the USDA-AQAS internal database in 2011).

As a consequence of intensive global trade and tourism, new pests and diseases are frequently introduced into Florida (Childers and Rodrigues, 2005; Magarey et al., 2009; Stack et al., 2006). The state has many nurseries and greenhouses that ship ornamental plants throughout the United States and other countries, including Canada. The value of ornamental plants exported from Florida to Canada was $\approx \$ 77$ million in 2010 (USDA-FAS, 2011). Thus, Florida has the potential to be a major conduit for the introduction and spread of new invasive pests and diseases which could, if not mitigated, have a serious impact on agriculture and the food supply of both the United States and Canada. About 863 million imported plants were processed at USDA, Animal and Plant Health Inspection Service (APHIS), Plant Protection and Quarantine (PPQ) Plant Inspection Station in Miami (MIA) in 2010 (calculated from the USDA-AQAS internal database in 2011). Only $2 \%$ of the 863 million imported plants are inspected at the MIA Plant Inspection Station (F.E. Lenis, personal communication). Because the number of imported plants entering Florida is so large and the number of plants that are actually inspected at the ports is so small, there is ample opportunity for new plant pests and diseases to enter Florida and

\begin{tabular}{llll}
\hline $\begin{array}{l}\text { Units } \\
\begin{array}{l}\text { To convert U.S. to SI, } \\
\text { multiply by }\end{array}\end{array}$ & U.S. unit & SI unit & $\begin{array}{l}\text { To convert SI to U.S., } \\
\text { multiply by }\end{array}$ \\
\hline 0.4047 & acre(s) & ha & 2.4711 \\
0.0929 & $\mathrm{ft}^{2}$ & $\mathrm{~m}^{2}$ & 10.7639
\end{tabular}


become distributed throughout Florida, the United States, and Canada. However, USDA-APHIS-PPQ has made and continues to make a substantial effort to inspect and detect exotic pests and diseases at the MIA Plant Inspection Station.

Some plant pathogens can be introduced into the United States on an ornamental host but may subsequently spread to a food crop. For example, the bacterial plant pathogen Ralstonia solanacaerum race 3 biovar 2 (R3B2) was introduced into the United States from Kenya in 2003 on geranium (Pelargonium sp.) cuttings but was eradicated. In early 2004, R3B2 was introduced into the United States again on geranium cuttings from Guatemala (USDAAPHIS-PPQ, 2004). R3B2 is a regulated, quarantine plant pathogen and is on the USDA select agent list (USDA-APHIS, 2011). It causes southern wilt on geranium and brown rot (bacterial wilt) on potato (Solanum tuberosum) and if allowed to become established could cause considerable harm to the potato industry in the United States (Champoiseau et al., 2009). The history of R3B2 introductions into the United States provides an excellent example of the necessity of inspection and certification programs for the ornamental nursery industry. These programs may prevent the spread of a serious plant pest or pathogen via ornamental propagative material to a major food crop, thereby preventing a serious threat to the U.S. food supply. Similarly, the insect melon thrips (Thrips palmi) was introduced into England on chrysanthemums (Chrysanthemum sp.) but was successfully eradicated at great costs, preventing potential economic damage for the ornamental and vegetable industries (MacLeod et al., 2004).

Several other important diseases of ornamentals such as sudden oak death caused by the oomycete Phytophthora ramorum and the dutch elm fungal disease caused by Ophiostoma sp. were introduced into the United States on infected plant material into one state and later spread to other states on infected plant material. Other diseases such as the cypress canker disease caused by the fungus, Seiridium cardinale, was recently shown to have been introduced from California into Asia, Europe, Australia, South America, and Africa (Della Rocca et al., 2011). These reports underline the importance of certifying plant material to be disease-free before they are distributed. Development and implementation of certification programs will contribute to preventing plant disease epidemics.

\section{Certification and inspection programs in Europe}

Recognizing the importance of certification programs in reducing the spread of plant pests and diseases, the European and Mediterranean Plant Protection Organization (EPPO) has developed certification schemes for both fruit and ornamental crops (Lopian, 1994). To date, there are EPPO certification schemes for 19 ornamentals (EPPO, 2011). Some countries in the European Union have developed certification programs that are more stringent than the EPPO certification schemes, particularly the Netherlands. The Netherlands General Inspection Service (NAK) administers obligatory and voluntary certification programs that include a voluntary audit-based certification program called the plant passport program, which is similar to yet more stringent than the USGCP (NAKtuinbouw, 2005). NAK has a list of standards that growers and traders must follow. In addition, an inspector conducts regular inspections of plant material in the nursery in conjunction with an annual audit of the administrative records (NAKtuinbouw, 2011).

\section{Nursery inspections in the United States}

The nursery industry in the United States is regulated by USDA-APHISPPQ and by state agriculture regulatory agencies. APHIS is directly concerned with the import of nursery stock from foreign sources and the export of plant material to foreign sources. In addition, APHIS regulates the interstate movement of nursery stock. Accredited state agencies are concerned with and administer both federal and state rules and regulations. State agriculture agencies monitor the nurseries and conduct certification inspections. State agencies and state regulatory officials that are proximally located to the nurseries allow for improved efficacy and efficiency of inspection. Nursery inspections have become more challenging for state agencies due to the increase in international travel and global trade, which has led to an increase in the number of invasive pests and diseases. At the same time, resources for state agencies have decreased. There has been an increasing tendency for federal and some state agencies to shift the responsibility for pest and disease surveillance to nurseries, thereby cutting costs for taxpayers and the government. In the early 1990s, the USDA recognized the need for an audit-based certification program that would increase a nursery's responsibility and reduce the number of phytosanitary inspections that state agencies would have to conduct (National Plant Board, 2011).

In 1998, the audit-based USGCP was instituted. This nationwide program run by USDA-APHIS for ornamental nurseries that export plants to Canada serves to produce highquality, low-risk decorative plants that are free of pests and diseases, to minimize the introduction and spread of new pests and diseases, and to meet the import standards of Canada (USDA-APHIS, 2009). There are currently $\approx 65$ nursery operations participating in the USGCP nationwide. A nursery operation may consist of several nursery sites; the total number of sites participating in the USGCP is 152. The USGCP nurseries are located in eight states. A preliminary feasibility study of audit-based certification and systems approaches to reduce the spread of plant pests and diseases in the United States was carried out recently (Thompson, 2011); however, detailed questionnaires were not included in the study.

\section{The U.S. Greenhouse}

\section{Certification Program in Florida}

In Florida, the USGCP is administered by the Florida Department of Agriculture and Consumer Services, Division of Plant Industry (FDACSDPI). At the time of this study, there were $\approx 48$ nurseries (including 127 sites) participating in the program in Florida.

When a nursery that is not in the USGCP is planning to export a shipment of plants to Canada, a DPI inspector must inspect the shipment before it leaves the nursery. If the shipment is found to be free of pests and diseases, the inspector signs a federal phytosanitary certificate and releases the 
shipment for export to Canada. The USGCP allows a nursery to bypass the pre-export inspection for shipments to Canada. Nurseries that are participating in the USGCP do not need to have a DPI inspector inspect a shipment that is going to Canada, and the shipment does not require a federal phytosanitary certificate. A USGCPparticipating nursery is already certified to export to Canada and can use the USDA-APHIS Export Certification Label issued by DPI. The label is affixed to the bill of lading where it is visible for inspectors at the Canadian border. A nursery must fulfill certain requirements to be in the USGCP. The nursery is required to be audited by DPI annually. During the audit, DPI inspects the shipment records and the spray records. If the audit is passed, the nursery receives the FDACS-DPI compliance agreement and is issued a specific number of Export Certification Labels. In addition to the audit, all of the plant material must be inspected quarterly by DPI inspectors. There are several additional requirements for a nursery to be in the program. The requirements are outlined in the USDA-APHIS USGCP compliance agreement and the FDACSDPI compliance agreement (FDACSDPI, 2006; USDA-APHIS, 2009).

To evaluate the effectiveness of the USGCP program and determine what modifications and improvements might be necessary, an assessment of the program was carried out by conducting a survey and holding two workshops among participants. The objectives of this research were to 1 ) determine whether growers were satisfied with the USGCP, 2) determine whether the program was successful in reaching both large and small nurseries, 3) determine whether growers were in adherence to the requirements of the USGCP and if not, what the possible barriers might be to adherence, and 4) determine whether growers would like to have input into the development of a new audit-based certification program. This research provides baseline data on the efficacy and success of the USGCP and will be used as a basis for comparison after development of a new and improved audit-based certification program that is currently in the planning stage.

\section{Materials and methods \\ Survey of ornamental nurseries}

SURVEY DEVELOPMENT AND DESIGN. A survey of 44 USGCP participating ornamental nurseries in Florida was conducted from Jan. to June 2011. This survey constitutes more than $90 \%$ of the total population of participating nurseries in Florida. The survey questionnaire was designed based on the USGCP requirements as listed in the USGCP national compliance agreement and the FDACS-DPI compliance agreement for export of ornamental greenhouse grown plants to Canada. The questionnaire consisted of 34 questions. Additional information was collected on the number of acres in production, the number of employees, and whether the nursery had only indoor production areas or both indoor and outdoor production areas. Production areas that are completely out in the open (not under cover) and in open-sided screenhouses were considered to be "outdoor" for our research project. The majority of questions were multiple choice; several were in a short answer format. The survey covered the following topics: 1) importation of plant propagative materials including regions of origin of those materials, segregation of imported and domestic plant material, and tracking of imported materials as they go through their growing cycle; 2) exportation of plant material to Canada, including examining the shipment area for pests and plant material for pests and diseases, export shipment records, inspection of shipment records, and the most common types of imported plants that are exported to Canada; 3 ) management of pests and diseases including examination by the nursery of incoming imported plant material for pests and diseases, treatment rendered if pests or diseases are found, types of plant materials that have the most problems with pests and diseases, the most common pests and diseases, written description of procedures used to control pests and diseases, scouting frequency, and spray documentation; 4) questions about the USGCP related to nursery personnel's understanding of the program requirements, amount of work required to be in the USGCP, whether there is an economic advantage to being in the program, and whether a checklist of USGCP requirements for nursery personnel would be helpful.

Conducting the survey. The survey was conducted in two parts. The initial survey consisted of 30 questions that had multiple choice or short answers. The survey was conducted in person at nurseries throughout central and southern Florida over a 3-month time period. The nurseries were located in Hardee, Highlands, Hillsborough, Lake, Miami-Dade, Orange, Palm Beach, and St. Lucie counties of Florida. Each nursery visit took $\approx$ l-2 h. Survey questions were asked to nursery owners, managers, head growers, and pest control managers during the visit while observing the plant production areas as much as possible. The responses from participants at each nursery to each question on the questionnaire were totaled, and percentage of responses for each possible answer was calculated.

After the responses were totaled and results determined, they were reported during a cooperator meeting at APHIS Headquarters in Riverdale Park, MD. As a result of the meeting, four additional questions were added to the survey. A phone survey was conducted to ask the same nurseries the additional questions.

Confidentiality regarding which nurseries were surveyed and the responses provided by each individual nursery was maintained throughout the project.

\section{Statistical analysis of survey}

The CHI SQUARE TEST. Nursery responses for each survey question were analyzed for significant differences between regions, acreage, gender, number of employees, and whether nurseries had only indoor production areas or both indoor and outdoor production areas. To examine regional effects, nurseries were placed in either the central or southern region of Florida based on the latitudes of the nurseries. Nurseries located at latitude $27^{\circ} \mathrm{N}$ or above were placed in central Florida. Nurseries located below latitude $27^{\circ} \mathrm{N}$ were placed in southern Florida. To analyze differences in responses for acreage, nurseries were separated into two size groups: small (0.5-10.5 acres) or large (14-200 acres). At several nurseries, the nursery owner would respond to some questions and a grower would respond to other questions. Several nurseries were placed in different gender groups for different questions depending on who answered the questions. To examine the size of the enterprise with respect to number of employees, nurseries were separated into nurseries with 19 or fewer 
employees or nurseries with 20 or more employees. To analyze effects of open-air exposure of the plants on the responses, nurseries were separated into those with only indoor production areas or with both indoor and outdoor production areas.

Student's T-TEST. The Student's $t$ test (two-tailed distribution, nonpaired, two-sample equal variance) was conducted on the responses to the survey questions involving percentage of total nursery plant inventory imported from offshore and the percentage of imported plants that are exported to Canada. Data were analyzed for significant differences between region, acreage, gender, number of employees, and whether nurseries had only indoor production areas or both indoor and outdoor production areas. Nurseries were grouped into the categories using the same criteria as used with the chi square tests.

\section{Workshops on the U.S.-Canadian Greenhouse Certification Program}

Two $1-d$ workshops were held to facilitate a discussion between nursery growers, scientists, and regulatory officials to discuss their perceptions of the strengths and weaknesses of the current USGCP and for the USDA to introduce proposed changes in an effort to receive feedback and input. In addition, the workshops were held to educate and encourage the use of rapid diagnostics as well as pest and disease management techniques to lower the risk of spread of new pests and diseases.

The first workshop took place on 12 Aug. 2011 at University of Florida (UF)/Institute of Food and Agricultural Sciences (IFAS) Mid-Florida Research and Education Center (MFREC) in Apopka, FL. The second workshop took place on 14 Sept. 2011 at UF/IFAS Tropical Research and Education Center in Homestead, FL. Each workshop consisted of the same program, although some of the presenters were different. The workshops consisted of three sections: 1) diagnostics, 2) USGCP, and 3 ) disease and pest management.

\section{Economics of participation in the U.S.-Canadian Greenhouse Certification Program}

Data on the costs of participation in the program were obtained from
FDACS-DPI personnel and growers participating in the workshops. These data were combined to estimate the additional costs attributed to participation in the USGCP.

\section{Results and discussion Survey of ornamental nurseries}

Descriptive Data. Diligent attempts were made to contact the complete population of nurseries enrolled in the USGCP in Florida and to obtain their participation for the survey. Of the 44 listed nurseries visited, 43 turned out to be currently participating in the USGCP. Of the 43 nurseries visited, 42 answered all of the questions in the initial survey. In the additional survey, 33 nurseries answered the four questions. Nurseries ranged in size from 0.5 to 200 acres. The number of employees at each nursery varied depending on the season. At the time of our survey, the approximate number of people employed at each nursery (including part-time and seasonal employees) ranged from 4 to 250 employees. Twenty-four nurseries were located in central Florida, and 20 were located in southern Florida. Twentyseven nurseries had production areas that were completely indoors, and 17 nurseries had both indoor and outdoor production areas.

IMPORTED PLANT MATERIAL. A majority $(82 \%)$ of the nurseries surveyed import plant material from outside of the United States. They import from a variety of regions and countries around the world including Central America/Caribbean (48\%), Asia (20\%), Europe (17\%), and South America (5\%). In addition, $8 \%$ of the nurseries import from Guinea, Israel, Madagascar, Mexico, Papua New Guinea, and/or South Africa (Fig. 1). The approximate percentages of total plant inventory that nurseries import range from $1 \%$ to $100 \%$.

Before the imported plant material is moved into the main production area, $97 \%$ of the nurseries carefully examine this material. At $59 \%$ of the nurseries, personnel conducting the initial examination are qualified to identify pests and diseases on incoming plant material. When incoming plant materials have pests or disease, nurseries apply pesticide (36\%), destroy the entire shipment (33\%), reject plant material and send the entire shipment back to the supplier (11\%),

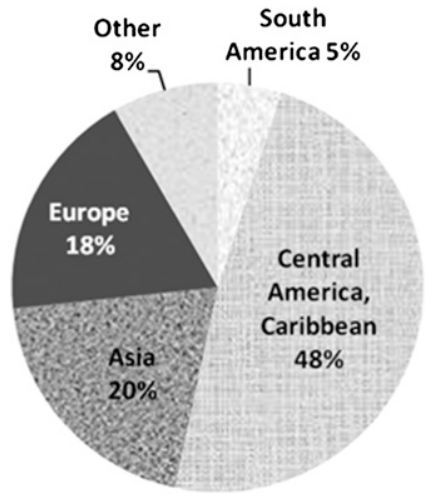

Fig. 1. Region of origin of plant material imported by Florida nurseries participating in the U.S.-Canadian Greenhouse Certification Program in 2011.

destroy only the part of the shipment in which the disease or pest was found $(9 \%)$, and keep the diseased or infested plants away from the main production area $(5 \%)$. Several nurseries (6\%) apply preventative pesticides before inspection of the plant material.

Nurseries participating in the USGCP are required to keep imported plant material segregated from domestic plant material. Growers responded that they always $(43 \%)$, often $(3 \%)$, sometimes $(6 \%)$, or never (49\%) keep imported plant material segregated from domestic plant material. In addition, nurseries are required to keep track of which plants were imported as the plants go through their growth cycles. Eighty-one percent of the nurseries do keep track of the plants that are imported.

Plant Material For EXPORT to CANADA. Plants that are to be exported to Canada under the USGCP are required to follow the guidelines of the program and compliance agreement. Most nurseries (80\%) always grow plants destined for Canada within an enclosed structure. However, several respondents said that they either often $(7 \%)$ or sometimes $(14 \%)$ grow the plants destined for Canada within an enclosed structure. When preparing shipments for export to Canada, 98\% respondents said that the plants being shipped were always inspected for pests and diseases, and $82 \%$ said that they inspect the shipment area for pests. Most respondents (84\%) said that their shipment records include the origin of the plant; however, the nursery location is usually listed as the geographic origin rather than the original source 
of the plant propagative material. All respondents $(100 \%)$ said that the export shipment records include the name of the plant.

The number of shipments exported to Canada per month is important in determining whether a nursery can be in the USGCP. Thirteen nurseries $(30 \%)$ responded that the number of shipments exported to Canada per month varied with the season; there are more shipments to Canada during the busy season (late spring, early summer) than during the off season. Five nurseries $(11 \%)$ ship to Canada less than once per month, 13 nurseries (30\%) ship one to four times per month, eight nurseries (18\%) ship five to eight times per month, and five nurseries (11\%) export 10 or more shipments per month. FDACS-DPI requires nurseries in the central region of Florida to export a minimum of 10 shipments to Canada per month to be in the USGCP. A minimum of five shipments per month are required for nurseries located in the southern region of Florida. The reason for the difference in the minimum number is unclear.

Nurseries were asked what percentage of imported plants in each nursery are shipped to Canada; responses ranged from $1 \%$ to $75 \%$. Nursery responses for the top imported plant species that are exported to Canada were totaled and ranked. Twelve nurseries reported that dracaena (Dracaena sp.) was the imported plant species most commonly shipped to Canada, followed by six nurseries for croton (Croton sp.), five nurseries for palms (family Arecaceae), and four nurseries for sansevieria (Sansevieria sp.). Bromeliads (family Bromeliaceae), ficus (Ficus sp.), pothos (Epipremnum aureum), and schefflera (Schefflera sp.) were each listed as the most common by three nurseries (Table 1 ).

MANAgement of PESTS AND DISEASES. To minimize the risk of transferring pests and diseases from regular plant inventory to nursery stock, nurseries participating in the USGCP are required to keep nursery stock in a location that is segregated from the rest of the plant material. A majority of nurseries (59\%) responded that they keep nursery stock segregated from the rest of their plant inventory. Nurseries were asked about the types of propagative plant materials that have the most problems with pests and diseases. The majority (53\%) responded that nonrooted cuttings have the most problems with pests and diseases, which is followed by bare-rooted cuttings (14\%) and liners $(10 \%)$. Eleven growers said they had the most disease and pest problems with other plant materials such as seeds, plugs, ferns (division Pteridophyta), or bromeliads (data not shown). The most common disease problems were reported to be caused by the plant pathogens Xanthomonas, Erwinia, Fusarium, Pythium/Phytophthora, and Myrothecium (Table 2). The most common pest problems were reported to be mites (suborder Prostigmata), thrips (order Thysanoptera), mealybugs (family Pseudococcidae), aphids (superfamily Aphidoidea), and fungus gnats (family Sciaridae) (Table 2).

Several requirements of the USGCP involve management of pests and diseases. Nurseries were asked four questions involving pest and disease management. More than half of the nurseries $(61 \%)$ participating in the USGCP do not keep a pest management plan or written description of the procedures used to control diseases and pests. Only 36\% keep a written description of procedures as required by the USGCP. The majority $(66 \%)$ said that they scout daily for pests and diseases. However, several respondents mentioned that although they do not have an organized schedule for scouting, they are constantly looking for pests and diseases in the course of their daily activities. A majority $(52 \%)$ of growers do not use sticky or pheromone traps. Many growers cited the high cost of traps as a barrier to using these pest management tools. A large majority (98\%) said that they always document pesticide control activities as required by the U.S. Environmental Protection Agency.

Nursery stafF INVOLVED IN ADHERENCE TO THE REQUIREMENTS. Most nurseries (86\%) reported that they always have a designated staff member who is responsible for understanding and carrying out the requirements of the USGCP. Some nurseries indicated that they do not know what the requirements are for the USGCP; and $30.2 \%$ of these nurseries agreed while $51.1 \%$ of them strongly agreed that it would be helpful to have a checklist of these requirements for nursery personnel to use. Some growers said that they depend on inspectors to let them know
Table 1. Highest ranked imported plants that were exported to Canada from nurseries in Florida that were participating in the U.S.-Canadian Greenhouse Certification Program.

\begin{tabular}{llc}
\hline Rank & \multicolumn{1}{c}{ Plant } & $\begin{array}{c}\text { Nurseries } \\
\text { (no.) }\end{array}$ \\
\hline 1 & Dracaena & 12 \\
2 & Croton & 6 \\
3 & Palms & 5 \\
4 & Sansevieria & 4 \\
5 & Bromeliads, & 3 each \\
& ficus, pothos, \\
& schefflera (tied) \\
\hline
\end{tabular}

Table 2. Most important plant pathogens and pests found in nurseries in Florida that were participating in the U.S.-Canadian Greenhouse Certification Program as reported by growers.

\begin{tabular}{lll}
\hline Rank & \multicolumn{1}{c}{ Pathogen $^{\text {z }}$} & \multicolumn{1}{c}{ Pest } \\
\hline 1 & Xanthomonas (B) & Mites \\
2 & Erwinia (B) & Thrips \\
3 & Fusarium (F) & Mealybugs \\
4 & Pythium/ & Aphids \\
& Phytophthora (O) & \\
5 & Myrothecium (F) & Fungus \\
& & gnats \\
\hline${ }^{2} \mathrm{~B}=$ bacterium, $\mathrm{F}=$ fungus, $\mathrm{O}=$ oomycete.
\end{tabular}

whether they are in compliance and what they need to change if they are not in compliance.

\section{Statistical analysis of survey}

THE CHI SQUARE TEST. Nursery responses to three survey questions exhibited statistically significant differences at $P<0.05$ when grouped by region, acreage, number of employees, and indoor only or both indoor and outdoor production areas.

1. Importation of planting materials. Significantly more nurseries with $\geq 20$ employees import plant materials from outside of the United States than nurseries with fewer employees. There were no significant differences when nurseries were grouped by region, size, or production area.

2. Growing plant materials in enclosed structures. Significantly more growers in central Florida that have smaller nurseries and only indoor production areas always grow plants destined for Canada in an enclosed structure compared with growers in southern Florida that have larger nurseries and both indoor and outdoor 
production areas (Table 3 ). None of the growers in central Florida answered that they grow plants for Canada outdoors, while eight growers in southern Florida with larger nurseries and both indoor and outdoor production areas answered that they sometimes grow plants destined for Canada outdoors. This difference can be explained by the fact that the majority of nurseries in central Florida were smaller and had only indoor production areas, while the majority of nurseries in southern Florida were larger and had both indoor and outdoor production areas.

3. Keeping imported material separate from domestic material. Significantly more nurseries with less than 20 employees reported that they never keep imported plant material separated from domestic plants compared with nurseries with more than 20 employees. The other growers responded that they always, often, or sometimes keep imported plant material segregated from domestic plant material. Responses to this question were not significantly affected by region, nursery size, or production area. Although it is unclear why nurseries with more employees are able to keep imported plant material segregated from domestic plant material, it is possible that having a well-staffed nursery allows growers to allocate this important task to a specific person. Another reason may be that keeping imported and domestic plant material segregated is labor intensive.

Some data were not suitable for chi square analysis due to too low frequencies in certain classes. All other nursery responses in which chi square analysis could be performed exhibited no statistically significant differences.

STUDENT's T-TEST. There were no significant differences in percentages of plant materials imported from offshore and of imported plants that are exported to Canada between groups at the $95 \%$ confidence level.

\section{Workshops on the U.S.-Canadian Greenhouse Certification Program}

Several topics of discussion were common to both workshops, particularly concerning the ambiguous terminology in the USGCP requirements. The terms that participants thought were ambiguous were "segregated," "domestic," and "growing cycle" (or "cycle of vegetative growth"). The USGCP requires that nurseries keep imported plants segregated from domestic plants. However, the compliance agreements do not specify the distance between imported and domestic plants that would be necessary to fulfill the requirement. It is not clear whether imported plants can be in the same room as domestic plants or whether they must be kept in separate rooms or greenhouses. Participants said that the requirement to keep imported and domestic plants segregated would not be financially practical if that would mean that imported and domestic plants had to be kept in separate greenhouses.

The FDACS-DPI compliance agreement states that imported plants must be segregated until they have completed a significant cycle of growth (FDACS-DPI, 2006). There is much variation in growth cycles among plants depending on the plant species, and participants wondered how much

Table 3. Chi square results for differences between region, acreage, and production area, when U.S.-Canadian Greenhouse Certification Program survey participants were asked whether plants destined for Canada were grown within an enclosed structure.

\begin{tabular}{|c|c|c|c|c|}
\hline Group $^{\mathrm{z}}$ & & $A^{y}$ & $\mathrm{O} / \mathrm{S}^{\mathrm{y}}$ & $\begin{array}{c}\text { Chi square, } \\
P<0.025\end{array}$ \\
\hline \multirow[t]{2}{*}{ Region } & Central & 23 & 1 & 8.6 \\
\hline & South & 12 & 8 & \\
\hline \multirow[t]{2}{*}{ Acreage } & Small & 21 & 1 & 6.8 \\
\hline & Larger & 14 & 8 & \\
\hline \multirow[t]{2}{*}{ Production } & Indoor & 26 & 1 & 12 \\
\hline & Indoor + outdoor & 9 & 8 & \\
\hline
\end{tabular}

${ }^{2}$ Central $=$ nurseries located at lat. $27^{\circ} \mathrm{N}$ or above, South $=$ nurseries located below lat. $27^{\circ} \mathrm{N}$, Small $=$ nurseries between 0.5 and 10.5 acres, Large $=$ nurseries between 14 and 200 acres, Indoor $=$ nurseries with greenhouse and or screenhouse production areas only, Indoor + outdoor $=$ nurseries with greenhouse and/or screenhouse, and outdoor production areas; 1 acre $=0.4047$ ha.

${ }^{\mathrm{y}} \mathrm{A}=$ always, $\mathrm{O} / \mathrm{S}=$ often $/$ sometimes growth do imported plants have to be incorporated into the domestic plant inventory. It is unclear as to whether imported plants can be considered domestic plants after they have completed a growing cycle. In addition, one of the USDA compliance agreement requirements that refer to the presence of nonregulated plant pests states that "practically free means not to exceed a $2 \%$ infestation level of nonregulated pests"(USDA-APHIS, 2009). Participants wondered whether the percentage referred to $2 \%$ of the total shipment, $2 \%$ of the total amount of plants in the nursery that were hosts of the pest, or $2 \%$ of the total amount of plants in the nursery. It was also not clear if the percentage refers to incidence (number of plants infested) or severity (percentage of foliage area infested).

Participants at both workshops discussed the requirement that nurseries must have a pest management program. Most nurseries surveyed have a plan for handling disease and pest problems; however, most do not have a document detailing the management plan. The USDA is considering providing nurseries with a computerized pest management plan template or form. Participants said that they would be willing to keep documented pest management plans as long as they were provided with a computerized template or form in which all they would have to do is enter some information, print out the form, put it in a three-ring binder, and place the binder with all of the pest management plans in an accessible location of the nursery. Growers also indicated that they would like to have input into the development of any changes made to the requirements of the USGCP.

\section{Economics of participation in the U.S.-Canadian Greenhouse certification program}

Nurseries that are not participating in the USGCP have to call DPI for an inspection each time there is a shipment to Canada. The fee for this inspection is a minimum of $\$ 50$ ( $\mathrm{T}$. Emery, personal communication). The DPI inspector issues a federal phytosanitary certificate after the nursery has passed the inspection and met Canadian phytosanitary entry requirements. The $\$ 50$ fee includes the inspection and the phytosanitary certificate. In addition, 
the nursery is charged for the inspector's mileage to and from the DPI office (Table 4).

Nurseries that are participating in the USGCP are required to have a quarterly certification inspection. DPI charges $\$ 50$ per site for the quarterly inspection. Some nurseries have two or more sites. The nursery is charged $\$ 50$ for each site regardless of how close together the sites are located. In addition, the nursery is charged for the inspector's mileage to and from the DPI office. Nurseries are audited annually by DPI. The audit includes inspection of the shipment and spray records. The fee for the annual audit is $\$ 50$. A comparison of the costs for the inspections reveals considerable cost savings for nurseries participating in the USGCP (Table 4).

The USGCP labels are typically approved at the beginning of the state fiscal year when the FDACS-DPI compliance agreement is filled out and signed. DPI sends the label file to a printer selected by the nursery and authorizes the printing of a certain quantity of labels for the specified nursery. The nursery does not have to pay a fee for the labels; however, they do have to pay to have the labels printed. The cost of printing varies with the printer that is used.

Altogether, the cost savings for participating in the USGCP are substantial, especially for nurseries that frequently export to Canada (Table 4). Rather than paying DPI $\$ 50$ for each inspector visit, the nursery pays a minimum of $\$ 50$ for each quarterly inspection.

\section{Comparison with other audit- based certification systems}

Newcomer and Derrick-Mills (2011) evaluated the U.S. Nursery Certification Program, a pilot program for ornamental nurseries (not necessarily in greenhouses) that export plant material to Canada on a qualitative basis. The participating growers were proud to be part of this pilot program, but several thought that the number of participants was too low, that the information provided about the program was insufficient, and some feared that the required documentation was too extensive to be practical. Thus, the qualitative outcomes of that survey confirm some of the results obtained through our questionnaire.

There are many other audit-based certification programs worldwide. The certification programs cover both food and ornamental crops. For example, certification programs exist for bulb production, fisheries, forest management, and fruit production (EPPO, 2011; Johansson and Lidestav, 2011; McNamara, 1996). These programs are mostly geared toward environmental sustainability, social justice, food safety, freedom from pests and diseases, and product quality. Typical examples are good agricultural practices certification, Fair Trade, and organic certification. In all cases, certification agencies are overseen by accreditation bodies, and the certified producers

Table 4. Comparison of costs associated with inspections for shipments to Canada for nurseries not enrolled in the U.S.-Canadian Greenhouse Certification Program (USGCP) and nurseries enrolled in the USGCP in Florida in $2011 .^{2}$

\begin{tabular}{|c|c|c|c|}
\hline & \multicolumn{3}{|c|}{ Shipments (no./mo.) } \\
\hline & 5 & 10 & 15 \\
\hline \multicolumn{4}{|l|}{ Shipments to Canada (not in USGCP) } \\
\hline $\begin{array}{l}\text { Cost of inspection and phytosanitary } \\
\text { certificate per shipment }\end{array}$ & $\$ 50.00$ & $\$ 50.00$ & $\$ 50.00$ \\
\hline Cost per mo. & $\$ 250.00$ & $\$ 500.00$ & $\$ 750.00$ \\
\hline Cost per year (12 mo.) & $\$ 3,000.00$ & $\$ 6,000.00$ & $\$ 9,000.00$ \\
\hline \multicolumn{4}{|l|}{ Shipments to Canada (enrolled in USGCP) } \\
\hline $\begin{array}{l}\text { Cost of } 90-\mathrm{d} \text { inspections per year } \\
(\$ 50 / \text { inspection })\end{array}$ & $\$ 200.00$ & $\$ 200.00$ & $\$ 200.00$ \\
\hline Cost of annual audit & $\$ 50.00$ & $\$ 50.00$ & $\$ 50.00$ \\
\hline $\begin{array}{l}\text { Extra administration } \\
\qquad(5 \mathrm{~min} / \text { shipment at } \$ 25 / \mathrm{h})\end{array}$ & $\$ 125.00$ & $\$ 250.00$ & $\$ 375.00$ \\
\hline Cost per year (12 mo.) & $\$ 375.00$ & $\$ 500.00$ & $\$ 625.00$ \\
\hline
\end{tabular}

need to abide by standards and keep records, which are inspected by the certification agencies. The effectiveness of certification in attaining the goals of a program has seldom been evaluated (Johansson and Lidestav, 2011; Wilson et al., 2009); therefore, it is difficult to compare the outcomes of the research reported here with similar research on other certification programs. However, it is generally acknowledged that participants adhere best to the requirements of a certification program when they are internally motivated to do so as a result of shared knowledge and attitudes by group learning and collaboration. In addition, they are motivated by peer pressure because failure to adhere to the requirements could damage other participants in the program (Pyburn et al., 2006). The USGCP may benefit from informal growers' groups to exchange knowledge and experiences and to improve overall program consistency and management.

\section{Conclusions}

The sales value of the ornamental floriculture industry in Florida was $\$ 909$ million in 2007 indicating that the ornamental industry is very important to Florida's economy. The USGCP plays an important role in allowing federal and state agencies to regulate the ornamental nursery industry in an efficient manner with diminished resources. In addition, the USGCP provides standards for nursery growers to meet phytosanitary export standards designed to help minimize the spread of pests and diseases.

Nursery growers are satisfied with the USGCP because there is an economic advantage for them to be in the program. In addition, growers said that although enrollment in the USGCP requires some additional work, they follow best management practices as a normal part of their business. Furthermore, growers appreciate the quarterly nursery inspections provided by DPI inspectors because the inspectors function as an extra set of eyes when scouting for pests and diseases. Nurseries that are not participating in the USGCP do not receive inspections of all of their plant material quarterly; they only receive phytosanitary inspections on plant shipments that are going to be exported to Canada.

Our research found that the USGCP is successful in reaching both 
large and small growers. With few exceptions, both types of growers responded similarly to the questions. There is some variation among growers in adherence to the requirements. The main reasons for the lack of adherence appear to be due to the ambiguous terminology in the compliance agreements, unawareness as to what the requirements are, and financial constraints. Nevertheless, growers generally strive to adhere to the requirements as best as they can as they have a strong motivation to be in compliance with the USGCP. Growers know that if their plant products are shipped to Canada with pests and/or diseases, the shipment will not be accepted at the Canadian port of entry. This rejection usually results in destruction of the plant material and an economic loss for the nursery.

The results of this survey are useful for developing an all-encompassing, audit-based certification system for the whole nursery industry, including both greenhouse and outdoor production. It is recommended to include participants in the USGCP in the development team of such a new program.

\section{Literature cited}

Champoiseau, P.G., J.B. Jones, and C. Allen. 2009. Ralstonia solanacearum race 3 biovar 2 causes tropical losses and temperate anxieties. Plant Health Prog., doi: 10.1094/PHP-2009-0313-01-RV.

Childers, C.C. and J.C.V. Rodrigues. 2005. Potential pest mite species collected on ornamental plants from Central America at port of entry to the United States. Fla. Entomol. 88:408-414.

Della Rocca, G., C.A. Eyre, R. Danti, and M. Garbelotto. 2011. Sequence and simplesequence repeat analyses of the fungal pathogen Seiridium cardinale indicate California is the most likely source of the cypress canker epidemic for the Mediterranean region. Phytopathology 101:14081417.

European and Mediterranean Plant Protection Organization. 2011. Production of healthy plants for planting. 20 Jan. 2012. <http://archives.eppo.org/ EPPOStandards/certification.htm>.

Florida Department of Agriculture and Consumer Services, Division of Plant Industry. 2006. Compliance Agreement/ U.S./Canada Greenhouse Certification Program. Florida Dept. Agr. Consumer Serv., Div. Plant Ind., Gainesville, FL.
Johansson, J. and G. Lidestav. 2011. Can voluntary standards regulate forestry? Assessing the environmental impacts of forest certification in Sweden. For. Policy Econ. 13:191-198.

Lopian, R. 1994. The activities of EPPO in relation to the improvement and harmonization of health standards for ornamental plants in the European and Mediterranean region. Acta Hort. 377:19-30.

MacLeod, A., J. Head, and A. Gaunt. 2004. An assessment of the potential economic impact of Thrips palmi on horticulture in England and the significance of a successful eradication campaign. Crop Prot. 23:601-610.

Magarey, R.D., M. Colunga-Garcia, and D.A. Fieselmann. 2009. Plant biosecurity in the United States: Roles, responsibilities, and information needs. Bioscience 59:875-884.

McNamara, D.G. 1996. The preparation of international certification and classification schemes for ornamental crops. Acta Hort. 432:212-217.

NAKtuinbouw. 2005. Handleiding Plantenpaspoort Bloemisterijgewassen. 28 Nov. 2011. <http://edepot.wur.nl/ $116814>$.

NAKtuinbouw. 2011. Plant Passport Guide for Companies. 22 Nov. 2011. <http://www.naktuinbouw.nl/en/article/ plant-passport-guide-companies>.

National Plant Board. 2011. A Systems Approach to Nursery Certification. 17 Nov. 2011. <http://nationalplantboard.org/ docs/sanc_NPB_White_Paper.pdf>.

Newcomer, K. and T. Derrick-Mills. 2011. Evaluation of the USDA/APHIS United States nursery certification program (USNCP). Prepared for Horticultural Research Institute, Inc. by Midge Smith Center for Evaluation Effectiveness Trachtenberg School of Public Policy and Public Administration, George Washington Univ., Washington, DC.

Pyburn, R., N. Sriskandarajah, and A.E.J. Wals. 2006. Social responsibility in organic agriculture: Learning, collaboration and regulation, p. 329-350. In: P. Kristiansen, A. Taji, and J. Reganold (eds.). Organic agriculture. A global perspective. CABI and CSIRO, Collingwood, Victoria, Australia.

Stack, J., K. Cardwell, R. Hammerschmidt, J. Byrne, R. Loria, K. Snover-Clift, W. Baldwin, G. Wisler, H. Beck, R. Bostock, C. Thomas, and E. Luke. 2006. The national plant diagnostic network. Plant Dis. 90:128-136.

Thompson, J.P. 2011. Certified: Feasibility of audit-based certification to prevent invasive plant pest in the horticulture industry. Northeast-Midwest Institute, Washington, DC.

U.S. Department of Agriculture, Animal and Plant Health Inspection Service. 2009. U.S. Canadian Greenhouse Certification Program. 3 Nov. 2011. <http:// www.aphis.usda.gov/plant_health/acns/ downloads/canadian_greenhouse.pdf>.

U.S. Department of Agriculture, Animal and Plant Health Inspection Service. 2011. National Select Agent Registry. 17 Nov. 2011. <http://www.selectagents. gov/resources/List $\% 20$ of $\% 20$ Select $\% 20$ Agents\%20and\%20Toxins\%2009-19-2011. pdf>.

U.S. Department of Agriculture, Animal and Plant Health Inspection Service, Plant Protection and Quarantine. 2004. Factsheet: Questions and Answers on Ralstonia solanacearum Race 3 Biovar 2. 17 Nov. 2011. <http://www.aphis.usda. gov/publications/plant_health/content/ printable_version/faq_phralstonia.pdf>.

U.S. Department of Agriculture, Foreign Agricultural Service. 2011. Global Agricultural Trade System. 17 Nov. 2011. <http://www.fas.usda.gov/GATS/ ExpressQueryl.aspx>.

U.S. Department of Agriculture, National Agriculture Statistics Service. 2007a. Census of Agriculture: United States Summary and State Data, Volume I U.S. Summary and State Reports, Chapter 1: U.S. National Level Data, Table 37. 24 Jan. 2012. <http://www.agcensus.usda. gov/Publications/2007/Full_Report/ Volume_1,_Chapter_1_US/st99_1_037_ 037.pdf>.

U.S. Department of Agriculture, National Agriculture Statistics Service. 2007b. Census of Agriculture: United States Summary and State Data, Volume 1 U.S. Summary and State Reports, Chapter 2: State Level Data, Table 35. 24 Jan. 2012. <http://www.agcensus.usda.gov/ Publications/2007/Full_Report/Volume_1,_Chapter_2_US_State_Level/ st99_2_035_035.pdf>.

U.S. Department of Agriculture, National Agriculture Statistics Service. 2011. Floriculture Crops 2010 Summary. 16 Nov. 2011. <http://usda01.library.cornell. edu/usda/nass/FlorCrop//2010s/2011/ FlorCrop-04-21-2011_new_format.pdf>.

Wilson, J.R., J.R. Vaegen-Lloyd, and C. Caponecchia. 2009. Workshop-based methodology to understand the risks in grain export inspection and certification. Ergonomics 52:759-773. 